\title{
PENGARUH PERILAKU TENAGA KESEHATAN TERHADAP KESIAPSIAGAAN BENCANA DI KABUPATEN NIAS UTARA TAHUN 2021
}

\author{
Eko Krisman Harefa ${ }^{1}$, Daniel Ginting ${ }^{2}$, Mido Ester J. Sitorus ${ }^{3}$, Donal Nababan ${ }^{4}$ \\ Kesehatan Masyarakat Direktorat Pascasarjana ${ }^{1}$ \\ Universitas Sari Mutiara Indonesia ${ }^{2,3,4}$ \\ midoester2211@gmail.com, Danielginting@gmail.com
}

\begin{abstract}
Disaster is an extreme disruption of the functioning of a society that causes widespread social, material and environmental harm and exceeds the ability of affected communities to cope by using only their own resources. The purpose of this study is to look at the Effect of Health Workers' Behavior on Disaster Preparedness in North Nias Regency in 2021. Types of analytical research with cross sectional design. This research was conducted at the North Nias Kanupaten Health Office. This research was conducted in August 2021 at the North Nias District Health Office. The population and samples in this study were all health workers in the Office of Health As many as 63 people and sampled. Data analysis is univariate, bivariate and multivariate analysis with Chi-Square test. The results of the chi-square statistic test analysis were obtained $p$ value $=0,000<0.05$ meaning there is an Influence of Respoden Knowledge on Disaster Preparedness in North Nias Regency year 2021. The results of the chi-square statistic test analysis were obtained $p$ value $=0,000<0.05$ meaning there is an effect of respoden attitude on Disaster Preparedness in North Nias Regency 2021. The results of the chi-square statistical test analysis were obtained $p$ value $=0.001<0.05$ meaning there is an Influence of Respoden Practice on Disaster Preparedness in North Nias Regency 2021. It is recommended that health workers can improve their knowledge of disaster preparedness and be more positive to prepare themselves to be involved in dealing with disasters.
\end{abstract}

Keywords $\quad$ : Behavior, Health Workers, Disaster Preparedness

\begin{abstract}
ABSTRAK
Bencana merupakan suatu gangguan ekstrim fungsi dari suatu masyarakat yang menyebabkan kerugian sosial, material dan lingkungan yang meluas dan melebihi kemampuan masyarakat terdampak untuk mengatasi dengan hanya menggunakan sumber daya sendiri Tujuan penelitian ini adalah untuk melihat Pengaruh Perilaku Tenaga Kesehatan Terhadap Kesiapsiagaan Bencana di Kabupaten Nias Utara Tahun 2021. Jenis penelitian analitik dengan desain cross sectional. Penelitian ini dilakukan di Kantor Dinas Kesehatan Kabupaten Nias Utara. Penelitian ini dilaksanakan pada bulan Agustus tahun 2021 di Kantor Dinas Kesehatan Kabupaten Nias Utara. Populasi dan sampel dalam penelitian ini adalah seluruh Tenaga Kesehatan di Kantor Dinas Kesehatan sebanyak 63 orang dan dijadikan sampel. Analisa data yaitu analisis univariat, bivariat dan multivariat dengan uji ChiSquare. Hasil analisis uji statistic chi-square diperoleh nilai $p$ value $=0,000<0,05$ artinya ada Pengaruh Pengetahuan respoden terhadap Kesiapsiagaan Bencana Di Kabupaten Nias Utara Tahun 2021. Hasil analisis uji statistic chi-square diperoleh nilai $p$ value $=0,000<0,05$ artinya ada Pengaruh sikap respoden terhadap Kesiapsiagaan Bencana Di Kabupaten Nias Utara Tahun 2021. Hasil analisis uji statistic chi-square diperoleh nilai $p$ value $=0,001<0,05$ artinya ada Pengaruh Praktik Respoden terhadap Kesiapsiagaan Bencana Di Kabupaten Nias Utara Tahun 2021. Sebaiknya tenaga kesehatan dapat meningkatkan pengetahuannya terkait kesiapsiagaan bencana dan dapat bersikap lebih positif untuk mempersiapkan diri terlibat dalam menghadapin bencana.
\end{abstract}

Kata Kunci : Perilaku, Tenaga Kesehatan, Kesiapsiagaan Bencana 


\section{PENDAHULUAN}

Indonesia merupakan salah satu negara paling rawan bencana di dunia, seringkali dan tidak terduga, yaitu di antaranya gempa bumi, tsunami, tanah longsor, letusan gunung berapi, banjir, dan kekeringan (CFE-DM, 2018). Indonesia berada di atas sabuk vulkanik (volcanic arc) yang memanjang dari Pulau Sumatera, Jawa, Nusa Tenggara dan Sulawesi, yang didominasi pegunungan vulkanik aktif, dan menyebabkan $87 \%$ wilayah Indonesia rawan bencana alam (Putra et al., 2015). Badan Nasional Penanggulangan Bencana (BNPB) mencatat pada 2017 terjadi 2.862 kejadian bencana alam, diantaranya banjir $(34,2 \%)$, puting beliung (31\%), tanah longsor $(29,6 \%)$, kebakaran hutan dan lahan (3,4\%), gempa bumi $(0,7 \%)$, kekeringan $\quad(0,6 \%), \quad$ gelombang pasang/abrasi $(0,4 \%)$, dan letusan gunung api $(0,1 \%)$ (BNPB, 2018).

Indonesia secara teratur terkena banjir, gempa bumi, tsunami, tanah longsor dan letusan gunung berapi, dan lain-lain menyebabkan hilangnya nyawa, perusakan harta benda, kemunduran ekonomi dan kerusakan lingkungan (BNPB, 2015). Berdasarkan Data sementara yang diperoleh dari BNPB, tercatat 2.341 kejadian bencana selama tahun 2017. Bencana alam yang terjadi di Indonesia berupa banjir sebanyak 787 kejadian, puting beliung sebanyak 716 kejadian, tanah longsor sebanyak 614 kejadian, kebakaran hutan dan lahan sebanyak 96 kejadian, banjir yang disertai tanah longsor sebanyak 76 kejadian, kekeringan sebanyak 19 kejadian, gempa bumi sebanyak 20 kejadian, gelombang pasang dan abrasi sebanyak 11 kejadian, dan letusan gunung api sebanyak 2 kejadian.

Kejadian bencana yang ada di Indonesia kebanyakan terjadi adalah bencana hidrometeorologi sekitar 90 persen, dimana bencana tersebut dipengaruhi oleh cuaca dan aliran permukaan. Seperti banjir, longsor, angin puting beliung dan kekeringan. Dari banyaknya bencana alam yang terjadi di Indonesia, bencana banjir adalah bencana yang paling sering terjadi, terutama pada musim hujan.

Provinsi Sumatera Utara merupakan wilayah yang berpotensi bencana gempa bumi yang dapat menimbulkan krisis kesehatan terutama pada kota-kota yang terletak pada daerah jalur patahan, seperti Tarutung, Padang Sidimpuan, Sibolga, Gunung Sitoli, dll pemukiman penduduk dilereng bukit dipantai barat dan disebelah barat pegunungan Bukit Barisan.

Berdasarkan data BPBD (2019) Kabupaten Nias Utara, kejadian bencana yang pernah terjadi sebagai berikut: bencana banjir terjadi pada tanggal 10 Maret 2011 dengan 2 kejadian dalam hari yang sama mengakibatkan 24 jiwa meninggal 622 rumah rusak berat dan 684 rusak ringan, bencana banjir dan tanah lonsor dengan 1 kali kejadian terjadi pada tanggal 26 januari 2007 yang mengakibatkan 38.809 jiwa mengunsi, bencana gempa bumi terbesar terjadi pada tanggal 2 November 2000 yang mengkibatkan 4 jiwa meninggal dan 254 jiwa luka-luka dan 802 rumah rusak berat, bencana gempa bumi dan tsunami terjadi sebanyak 2 kali kejadian pada hari yang sama kejadian pada tanggal 26 Desember 2004 mengakibatkan 9,292 jiwa meninggal, 2.925 jiwa hilang, 62.156 mengunsi, dengan kejadian tersebut maka BPBD tetap bersiap-siap untuk selalu waspada dengan kedatangan bencana kapan saja.

Dari survey awal yang dilakukan serta keterangan dari rumah sakit dan tenaga kesehatan, dimana akhir-akhir ini frekuensi dan intensitas kedahsyatan gempa bumi, banjir, angin puting beliung kita rasakan semakin meningkat sejak dalam 10 tahun terakhir. Oleh karena itu pemahaman gejala terjadinya bencana perlu ditingkatkan dan disikapi dengan tepat, kesalahan bersikap dalam menghadapi bencana perlu dihindari.

Berdasarkan permasalahan di atas maka peneliti tertarik untuk melakukan 
penelitian tentang Pengaruh Perilaku Tenaga Kesehatan Terhadap Kesiapsiagaan Bencana di Kabupaten Nias Utara Tahun 2021.

\section{METODE}

Jenis penelitian analitik dengan desain cross sectional, peneliti mencari pengaruh antara variabel bebas (risiko) yaitu sikap, pengetahuan, dan praktik atau pengalaman sebelumnya dalam penanggulangan bencana dengan variabel tergantung (efek) yaitu kesiapsiagaan bencana dengan melakukan pengukuran sesaat, desain cross sectional tidak ada prosedur tindak lanjut atau follow-up (Sastroasmoro, 2016). Penelitian ini dilakukan di Kantor Dinas Kesehatan Kanupaten Nias Utara.
Penelitian ini dilaksanakan pada bulan Agustus tahun 2021 di Kantor Dinas Kesehatan Kabupaten Nias Utara. Populasi dan sampel dalam penelitian ini adalah seluruh Tenaga Kesehatan di Kantor Dinas Kesehatan sebanyak 63 orang dan dijadikan sampel. Pengumpulan Data dalam penelitian. Data primer merupakan informasi yang dikumpulkan peneliti langsung dari objek penelitian atau responden selama penelitian. Pengolahan Data yang sudah terkumpul melalui kuesioner dilakukan pengolahan data untuk diproses. Penelitian, dengan menggunakan uji statistik. Analisis Univariat, Analisis Bivariat dan Analisis Multivariat.

\section{HASIL}

\section{Analisis Bivariat}

Tabel 1. Pengaruh Pengetahuan Tenaga Kesehatan terhadap Kesiapsiagaan Bencana Di Kabupaten Nias Utara Tahun 2021

\begin{tabular}{|c|c|c|c|c|c|c|}
\hline & & & \multicolumn{2}{|c|}{ Kesiapan tenaga kesehatan } & \multirow{2}{*}{ Total } & \multirow{2}{*}{ pValue } \\
\hline & & & Tidak siap & Siap & & \\
\hline \multirow[t]{6}{*}{ Pengetahuan } & Kurang & Count & 14 & 2 & 16 & \multirow{6}{*}{0,000} \\
\hline & & $\%$ of Total & $22,2 \%$ & $3,2 \%$ & $25,4 \%$ & \\
\hline & Cukup & Count & 9 & 10 & 19 & \\
\hline & & $\%$ of Total & $14,3 \%$ & $15,9 \%$ & $30,2 \%$ & \\
\hline & Baik & Count & 0 & 28 & 28 & \\
\hline & & $\%$ of Total & $0 \%$ & $44,4 \%$ & $44,4 \%$ & \\
\hline \multirow[t]{2}{*}{ Total } & & Count & 23 & 40 & 63 & \\
\hline & & $\%$ of Total & $36,5 \%$ & $63,5 \%$ & $100.0 \%$ & \\
\hline
\end{tabular}

Berdasarkan tabel 1. Hasil tabulasi silang pengaruh pengetahuan responden dengan kesiap tenaga kesehatan diperoleh bahwa dari 63 orang $(44,4 \%)$ diperoleh berpengetahuan baik sebayak 28 orang $(44,4 \%)$ dengan kesiapan tenaga kesehatan yang siap sebanyak 40 orang $(63,5)$. Sedangkan berpengetahuan kurang sebanyak 16 orang $(25,4 \%)$ dengan kesiapan tenaga kesehatan yang tidak siap sebanyak 23 orang $(36,5 \%)$. Hasil analisis uji statistic chi-square diperoleh nilai $\mathrm{p}$ value $=0,000<0,05$ artinya ada Pengaruh Pengetahuan respoden terhadap Kesiapsiagaan Bencana Di Kabupaten Nias Utara Tahun 2021.
Berdasarkan tabel 2. Hasil tabulasi silang pengaruh sikap responden dengan kesiap tenaga kesehatan diperoleh bahwa dari 63 orang $(44,4 \%)$ diperoleh bersikap negatif sebayak 33 orang $(52,4 \%)$ dengan kesiapan tenaga kesehatan yang siap sebanyak 40 orang $(63,5)$. Sedangkan bersikap positif sebanyak 30 orang $(47,6 \%)$ dengan kesiapan tenaga kesehatan yang tidak siap sebanyak 23 orang (36,5\%). Hasil analisis uji statistic chisquare diperoleh nilai $\mathrm{p}$ value $=0,000$ $<0,05$ artinya ada Pengaruh sikap respoden terhadap Kesiapsiagaan Bencana Di Kabupaten Nias Utara Tahun 2021. 
Tabel 2. Pengaruh Sikap Tenaga Kesehatan terhadap Kesiapsiagaan Bencana Di Kabupaten Nias Utara Tahun 2021

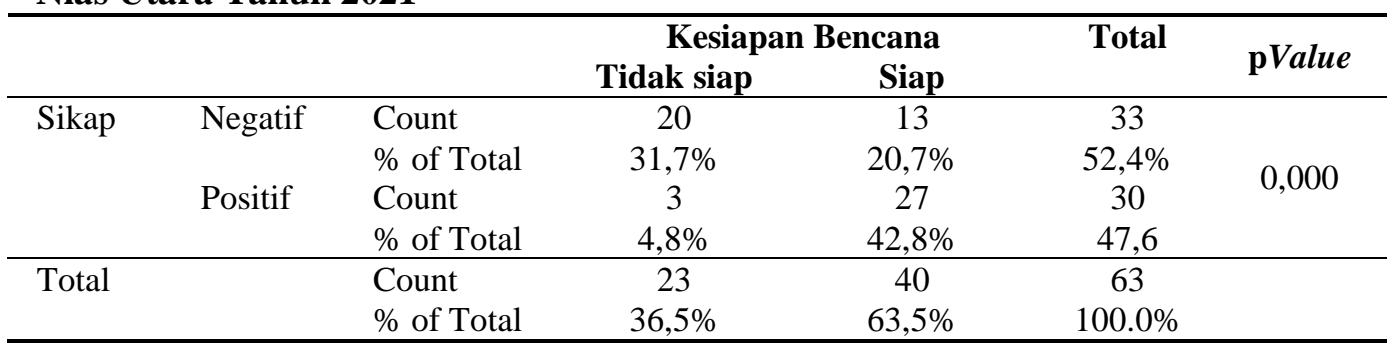

Tabel 3. Pengaruh Praktik atau Pengalaman sebelumnya Tenaga Kesehatan terhadap Kesiapsiagaan Bencana Di Kabupaten Nias Utara Tahun 2021

\begin{tabular}{|c|c|c|c|c|c|c|}
\hline & & & \multicolumn{2}{|c|}{ Kesiapan Bencana } & \multirow[b]{2}{*}{ Total } & \multirow[b]{2}{*}{ P Value } \\
\hline & & & Tidak siap & Siap & & \\
\hline \multirow[t]{6}{*}{ Praktik } & Kurang & Count & 7 & 6 & 13 & \multirow{6}{*}{0,001} \\
\hline & & $\%$ of Total & 11,1 & 9,5 & $20,6 \%$ & \\
\hline & Cukup & Count & 16 & 16 & 32 & \\
\hline & & $\%$ of Total & $25,4 \%$ & $25,4 \%$ & 50,8 & \\
\hline & Baik & Count & 0 & 18 & 18 & \\
\hline & & $\%$ of Total & $0 \%$ & 28,6 & 28,6 & \\
\hline \multirow[t]{2}{*}{ Total } & & Count & 23 & 40 & 63 & \\
\hline & & $\%$ of Total & $36,5 \%$ & $63,5 \%$ & $100.0 \%$ & \\
\hline
\end{tabular}

Berdasarkan tabel 3. Hasil tabulasi silang pengaruh pengetahuan responden terhadap kesiapsiagaan bencana diperoleh bahwa dari 63 orang $(44,4 \%)$ diperoleh Praktik yang cukup sebanyak 32 orang $(50,8 \%)$ dengan kesiapan tenaga kesehatan yang siap sebanyak 40 orang $(63,5)$. Sedangkan praktik yang kurang sebanyak 13 orang $(20,6 \%)$ dengan kesiapan tenaga kesehatan yang tidak siap sebanyak 23 orang $(36,5 \%)$. Sedangkan praktik yang baik sebanyak 18 orang $(28,6 \%)$ dengan kesiapan tenaga kesehatan siap sebanyak 40 orang $(63,5 \%)$. Hasil analisis uji statistic chisquare diperoleh nilai $\mathrm{p}$ value $=0,001$ $<0,05$ artinya ada Pengaruh Praktik Respoden terhadap Kesiapsiagaan Bencana Di Kabupaten Nias Utara Tahun 2021.

\section{Analisis Multivariat}

\section{Uji Regresi Logistik Binary (Logistic Regression) tahap pertama}

Adapun variabel yang diuji pada regresi berganda binary (logistic regression) tahap pertama ini adalah seluruh variabel independen yang telah dinyatakan signifikan $\mathrm{p}<0,25$ pada analisis bivariat. Hasil analisis variabel dengan uji regresi binary (logistic regression) tahap pertama dapat dilihat pada tabel 4 dibawah ini:

Tabel 4. Hasil Analisis Multiple Logistic Regression Dengan Masukan Seluruh Variabel Kandidat Dalam Model Omnibus Tests of Model Coefficients

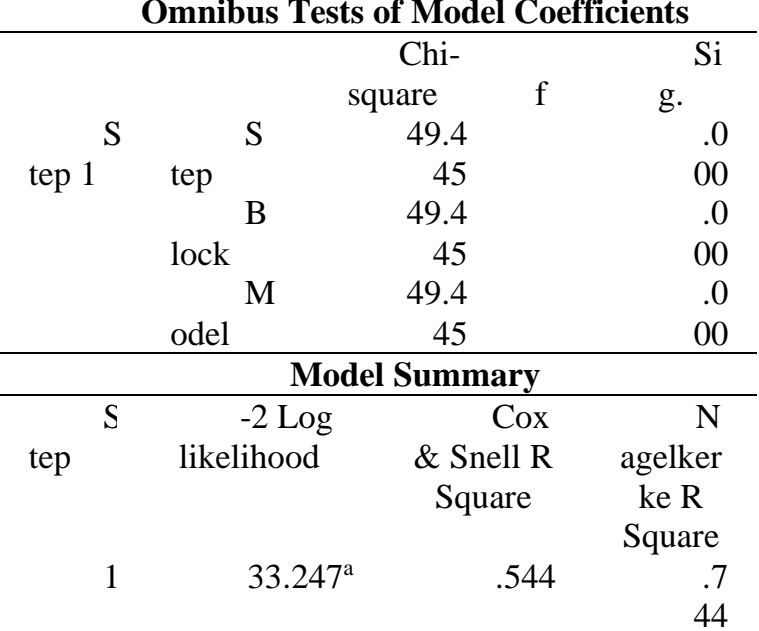

a. Estimation terminated at iteration number 7 because parameter estimates changed by less than .001 .

Nilai signifikan omnibus test harus berada dibawah 0.05, disimpulkan bahwa variabel bebas yang digunakan, secara bersama-sama berpengaruh terhadap ketepatan prediksi Kediapan tenaga kesehatan. Kemudian nilai nagelkerke R Square adalah 0,744 yang berarti bahwa variabel independen mampu menjelaskan $74,4 \%$ persen variabel dependen, 
Sedangkan 25,6\% lainnya dapat dijelaskan oleh faktor lain diluar variabel independen.

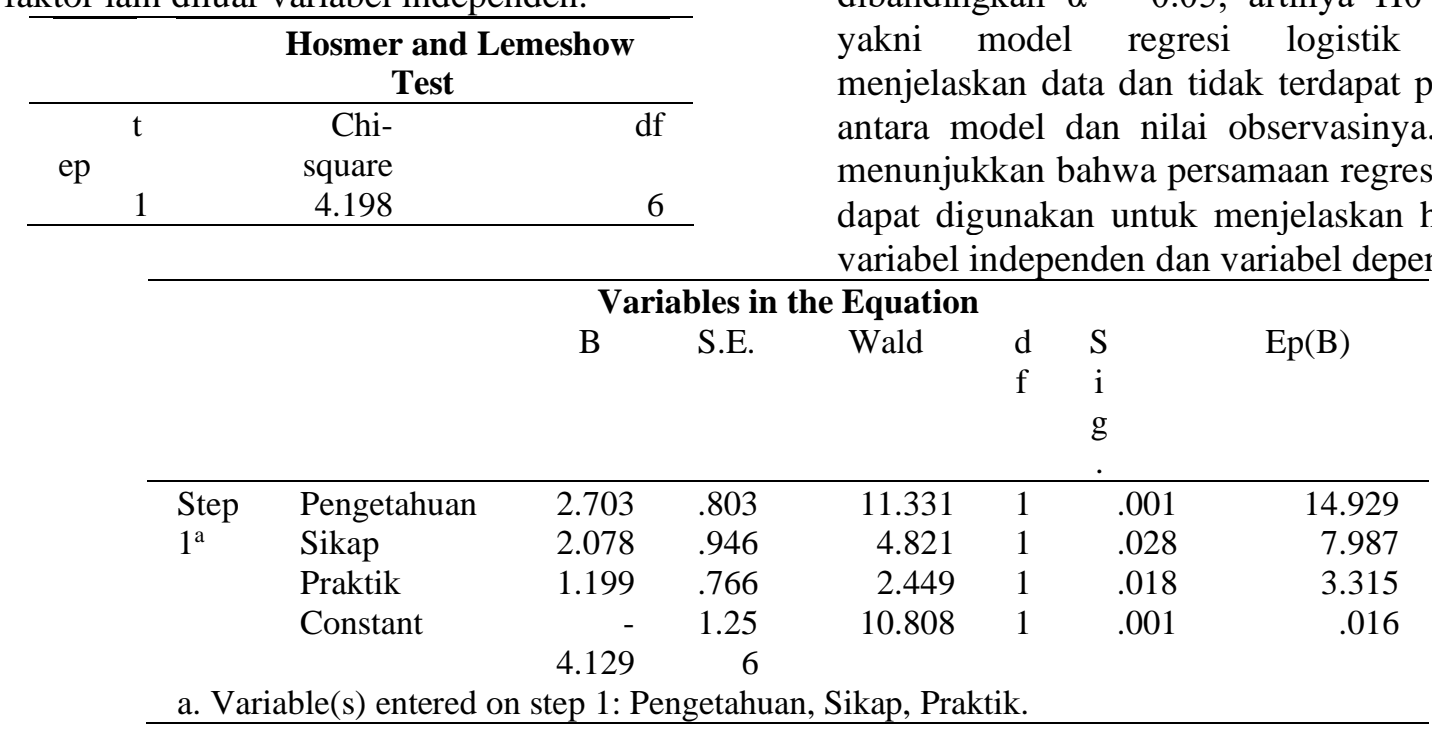

Hasil uji analisis regresi logistic, variabel pengetahuan $(0,001)$, sikap $(0,028)$ dan praktik $(0,018)$ berpengaruh secara signifikan terhadap kesiapan tenaga kesehatan. Pengetahuan mempengaruhi 14,929 kali kesiapan tenaga kesehatan. Semakin baik pengetahuan, maka semakin baik kesiapan tenaga kesehatan. Sikap mempengaruhi 7,987 kali kesiapan tenaga. kesehatan. Semakin baik sikap, maka semakin baik kesiapan tenaga kesehatan praktik mempengaruhi 3,315 kali kesiapan tenaga kesehatan. Semakin baik praktik, maka semakin baik kesiapan tenaga kesehatan. Dari tabel diatas dapat diambil persamaan: Kesiapan Tenaga Kesehatan = 4,129+2,703 Pengetahuan+2,078 Sikap+ 1.199 Praktik.

\section{PEMBAHASAN}

\section{Pengaruh Pengetahuan Tenaga Kesehatan terhadap Kesiapsiagaan Bencana Di Kabupaten Nias Utara}

Hasil tabulasi silang pengaruh pengetahuan responden dengan kesiap tenaga kesehatan diperoleh bahwa dari 63 orang $(44,4 \%)$ diperoleh berpengetahuan baik sebayak 28 orang $(44,4 \%)$ dengan kesiapan tenaga kesehatan yang siap sebanyak 40 orang $(63,5)$. Sedangkan berpengetahuan kurang sebanyak 16 orang
$(25,4 \%)$ dengan kesiapan tenaga kesehatan yang tidak siap sebanyak 23 orang $(36,5 \%)$. Hasil analisis uji statistic chi-square diperoleh nilai $\mathrm{p}$ value $=0,000<0,05$ artinya ada Pengaruh Pengetahuan respoden terhadap Kesiapsiagaan Bencana Di Kabupaten Nias Utara Tahun 2021.

Menurut Mubarak dkk (2017), faktor pendidikan, umur, minat, pengalaman, kebudayaan lingkungan sekitar, dan informasi juga dapat mempengaruhi rendahnya pengetahuan seseorang. Berdasarkan hasil penelitian menunjukkan bahwa pengetahuan pegawai rendah dalam hal kesiapsiagaan. Penelitian ini juga sejalan dengan penelitian Azadi dkk (2018) yang menyatakan bahwa pengetahuan kesiapsiagaan perawat Ilam masih rendah dengan presentase $59 \%$. Hal ini sejalan dengan penelitian Nisa dkk (2019) yang menyatakan bahwa pengetahuan kesiapsiagaan petugas kesehatan masih sangat rendah dengan presentase rendah 26 $\%$ dan sangat rendah $50 \%$.

Menurut peneliti tentang pengetahuan tenaga kesehatan yang sudah baik kirannya dipertahankan terus terutama dalam menghadapi bencana apapun yang terjadi misalnya bencana banjir, gempa, dan penyakit agar tidak banyak korban jiwa. 


\section{Pengaruh Sikap Tenaga Kesehatan terhadap Kesiapsiagaan Bencana Di Kabupaten Nias Utara}

Hasil tabulasi silang pengaruh sikap responden dengan kesiap tenaga kesehatan diperoleh bahwa dari 63 orang $(44,4 \%)$ diperoleh bersikap negatif sebayak 33 orang $(52,4 \%)$ dengan kesiapan tenaga kesehatan yang siap sebanyak 40 orang $(63,5)$. Sedangkan bersikap positif sebanyak 30 orang $(47,6 \%)$ dengan kesiapan tenaga kesehatan yang tidak siap sebanyak 23 orang $(36,5 \%)$. Hasil analisis uji statistic chi-square diperoleh nilai $\mathrm{p}$ value $=0,000<0,05$ artinya ada Pengaruh sikap respoden terhadap Kesiapsiagaan Bencana Di Kabupaten Nias Utara Tahun 2021.

Hasil penelitian ini menunjukkan bahwa sikap pegawai masih negatif terhadap kesiapsiagaan bencana. Hal ini tidak sejalan dengan penelitian Sruti dkk (2016) yang menyatakan bahwa sikap staff rumah sakit sudah positif tentang kesiapsiagaan bencana di rumah sakit umum india dengan presentase $83,3 \%$. Hal ini juga tidak sejalan dengan penelitian Naseer dan Huda (2018) yang menyatakan bahwa sikap petugas kesehatan Yaman sudah positif dalam kesiapsiagaan bencana dengan presentase $84,9 \%$.

Sikap merupakan faktor penentu perilaku karena sikap berhubungan dengan persepsi, kepribadian dan motivasi. Sikap diartikan sebagai kesiapsiagaan mental, yang dipelajari dan di organisasi melalui pengalaman, dan mempunyai pengaruh tertentu atas cara tanggap seseorang terhadap orang lain, objek, dan situasi yang berhubungan dengannya. Sikap dapat bersifat positif dan bersifat negatif. Sikap positif ditandai oleh kecenderungan tindakan yaitu mendekati, menyenangi, dan mengharapkan objek tertentu. Adapun, sikap negatif terdapat kecenderungan untuk menjauhi, menghindari, membenci dan tidak menyukai objek tertentu (Firmansyah dkk., 2014).

Menurut Peneliti dampak negatifnya sikap kesiapsiagaan bencana adalah saat terjadi bencana pegawai tidak dapat menolong diri sendiri maupun orang lain. Hal ini menyebabkan risiko korban semakin meningkat.

\section{Pengaruh Praktik atau Pengalaman sebelumnya Tenaga Kesehatan terhadap Kesiapsiagaan Bencana Di Kabupaten Nias Utara}

Hasil tabulasi silang pengaruh pengetahuan responden terhadap kesiapsiagaan bencana diperoleh bahwa dari 63 orang $(44,4 \%)$ diperoleh Praktik yang cukup sebanyak 32 orang $(50,8 \%)$ dengan kesiapan tenaga kesehatan yang siap sebanyak 40 orang $(63,5)$. Sedangkan praktik yang kurang sebanyak 13 orang $(20,6 \%)$ dengan kesiapan tenaga kesehatan yang tidak siap sebanyak 23 orang $(36,5 \%)$. Sedangkan praktik yang baik sebanyak 18 orang $(28,6 \%)$ dengan kesiapan tenaga kesehatan siap sebanyak 40 orang $(63,5 \%)$. Hasil analisis uji statistic chi-square diperoleh nilai $\mathrm{p}$ value $=0,001<0,05$ artinya ada Pengaruh Praktik Respoden terhadap Kesiapsiagaan Bencana Di Kabupaten Nias Utara Tahun 2021.

Hasil tersebut sejalan dengan penelitian Osman (2016) yang menunjukkan bahwa responden yang diteliti memiliki praktik yang memadai dengan presentase rata-rata $65,3 \%$. Namun hasil ini tidak sejalan dengan studi Mobi (2008) yang menunjukkan bahwa sebagian besar responden memiliki praktik yang tidak memadai.

Menurut peneliti walaupun tenaga kesehatan memiliki praktik yang cukup tetapi tenaga kesehatan harus lebih dominan apa pun untuk mempelajari satu rutinitas dan seharusnya tenaga kesehatan siap terlibat dalam penanggulangan bencana sehingga akan berpengaruh pada pengalaman yang dimiliki terkait kesiapsiagaan bencana apapun misalnya banjir, gempa bumi dan penyakit. 


\section{KESIMPULAN}

Kesimpulan yang dapat setelah dilakukannya penelitian adalah ada Pengaruh Pengetahuan Tenaga Kesehatan terhadap Kesiapsiagaan Bencana Di Kabupaten Nias Utara Tahun 2021. Ada Pengaruh Sikap Tenaga Kesehatan terhadap Kesiapsiagaan Bencana Di Kabupaten Nias Utara Tahun 2021.Ada Pengaruh Praktik atau Pengalaman Tenaga Kesehatan terhadap Kesiapsiagaan Bencana Di Kabupaten Nias Utara Tahun 2021.

\section{UCAPAN TERIMA KASIH}

Dalam penelitian ini, peneliti banyak mendapatkan bantuan dari berbagai pihak. Sehubungan dengan hal tersebut peneliti mengucapkan terima kasih kepada Kepala Dinas Nias Utara, Tenaga Kesehatan dan Ketua LPPM USM-INDONESIA.

\section{DAFTAR PUSTAKA}

Alwi Syafaruddin, 2005, Peningkatan Mutu Kinerja Kompetensi dan Motivasi SDM dalam Organisasi Pembelajaran, Magister Studi Islam-UII, Yogyakarta.

Berbasis Komonitas (PRBBK), PSMB-UPN. Jogjakarta. (PRB)Melalui Pendidikan Formal“. Jurnal Varia Pendidikan diakses 06 Februari 2020

$$
\begin{array}{ccc}
\text { BNPB (2014) } & \text { Rencana } & \text { Nasional } \\
\text { Penanggulangan } & \text { Bencana } & \text { 2015-2019. } \\
\text { Jakarta: www.bnpb.go.id. }
\end{array}
$$

BNPB (2015a) Kebijakan Strategis BNPB 2015-2019. Jakarta: www.bnpb.go.id.

BNPB (2015b) Rencana Strategis BNPB Tahun 2015-2019. Jakarta: www.bnpb.go.id.

BNPB (2017) 'Pengetahuan Kebencanaan', in BNPB. Jakarta: www.bnpb.go.id.

BNPB. (2017). "Data Informasi Bencana Indonesia"(http://dibi.bnpb.go.id/dibi/), diakses tanggal 08 Maret 2020.

BNPB (2018a) Tren Kejadian Bencana 10 tahun terakhir di Indonesia. Jakarta: www.bnpb.go.id.
BNPB (2018b) Tren Kejadian Bencana 10 Tahun Terakhir di Provinsi Nusa Tenggara Barat. Jakarta: www.bnpb.go.id.

Khambali, I. (2017) Manajemen Penanggulangan Bencana. 1st edn. Yogyakarta: CV. ANDI OFFSET.

Mubarak,dkk. (2017) Faktor-faktor perilaku yang memperngaruhi kesiapsiagaan bencana terhadap tenaga medis.

Paripurno, E. T. \& Jannah. N M. (Eds) (2014). Panduan Pengelolaan Resiko

Rahma, Aldila. (2018). "Implementasi Program Pengurangan Risiko Bencana

Tatuil, S., Mandagi, C. K. F. and Engkeng, S. (2015) 'Kajian Peran Tenaga Kesehatan Dalam Kesiapsiagaan Bencana Banjir di Wilayah Kerja Puskesmas Tuminting Kota Manado', Idea Nursing Journal, pp. 1-8. 